DOI: $10.15193 /$ zntj/2019/121/317

\author{
PATRYCJA SOWA, MARIA TARAPATSKYY, CZESŁAW PUCHALSKI, \\ MAŁGORZATA DŻUGAN
}

\title{
QUALITY EVALUATION OF CINNAMON MARKETED IN POLAND ON THE BASIS OF DETERMINING RATIO OF CINNAMALDEHYDE-TO-COUMARIN CONTENT
}

\author{
$\mathrm{S} u \mathrm{~mm}$ a r y
}

There are mainly two varieties of cinnamon available on the European market - Ceylon and Cassia cinnamon. Cassia cinnamon differs from Ceylon cinnamon in the taste, smell, appearance and, most of all, in the content of coumarin. Cassia cinnamon contains up to $10.6 \%$ of this compound, whereas Ceylon cinnamon contains only trace amounts thereof.

The objective of the research study was to assess the quality of cinnamon marketed in Poland using HPLC method. There were analysed twenty-six commercial samples in the form of powder $(n=19)$, sticks $(n=6)$ and bark $(n=1)$ in order to determine the contents of coumarin and cinnamaldehyde therein. Among them $73 \%$ had no information of their botanical origin shown on their labels (they were marked with the "unknown origin" indication). The samples labelled as Cinnamomum verum $(\mathrm{n}=6)$ or Cinnamomum cassia $(\mathrm{n}=1)$ were used as reference samples. The samples of unknown origin were characterised by the highest content of coumarin $(2.3 \div 7.7 \mathrm{mg} / \mathrm{g})$ and the C. verum and C. cassia samples by the lowest content thereof (up to $0.08 \mathrm{mg} / \mathrm{g}$ ). The cinnamaldehyde content was $38.7 \mathrm{mg} / \mathrm{g}-$ C. cassia, $19 \mathrm{mg} / \mathrm{g}$ - species of unknown origin and $9 \mathrm{mg} / \mathrm{g}-$ C. verum. The cinnamaldehyde-to-coumarin content ratio was highly differentiated. In the case of the samples with unknown origin that ratio was below 10, and the reference samples were characterised by a ratio $157 \div 680$. It was proved, that on the Polish market it was Cassia cinnamon, that was predominantly marketed as a low-cost spice with no producer's declaration of its botanical origin.

Key words: Cinnamomum, coumarin, cinnamaldehyde, HPLC analysis, verification of origin

Mgr inż. P. Sowa, dr inż. M. Tarapatskyy, prof. dr hab. inż. Cz. Puchalski, Katedra Bioenergetyki, Analizy Żywności i Mikrobiologii, Instytut Technologii Żywności i Żywienia, Uniwersytet Rzeszowski, ul. Zelwerowicza 4, 35-601 Rzeszów, dr hab. inż. M. Dżugan, prof. UR, Zakład Chemii i Toksykologii Żywności, Instytut Technologii Żywności i Żywienia, Uniwersytet Rzeszowski, ul. Ćwiklińskiej 1A, 35-601 Rzeszów.Kontakt:psowa@ur.edu.pl 


\section{Introduction}

Cinnamon is one of the oldest spices used in the food, pharmaceutical and cosmetic industries [2]. Its name is derived from the Greek words meaning sweet wood; it is obtained from a dried bark of the cinnamon tree (Cinnamomum) belonging to the Lauraceae family [5]. The Cinnamomum genus consists of 250 species, but only some of them are used for commercial purposes. There are two main varieties of cinnamon available on the European market - Ceylon and Cassia cinnamon. The Ceylon cinnamon, also known as ,true cinnamon”, is obtained from Cinnamomum verum J.Pres (syn. Cinnamomum zeylanicum Ness) cultivated in Sri Lanka, Madagascar and Southern India. Cassia cinnamon has many different botanical sources: Chinese cinnamon is a bark of Cinnamomum cassia Blume (syn. Cinnamomum aromaticum Ness), which is grown in China, Myanmar and Vietnam; the Indonesian cinnamon (korintje) Cinnamomum burmannii Blume originates mainly from Indonesia and Sumatra; and Vietnamese cinnamon (or Saigon cinnamon) from Cinnamomum loureirii Nees., mainly from the northern regions of Vietnam and southern China [2, 5, 10, 14]. Cassia cinnamon is cheaper than Ceylon cinnamon and therefore more available on the European market. In addition many producers do not provide information about the botanical origin of those spices $[1,12]$.

Cassia cinnamon differs from Ceylon cinnamon in the taste, smell, appearance of sticks and most importantly in their chemical composition, predominantly in the content of coumarin [2]. Cassia cinnamon contains up to $10.6 \%$ of coumarin, whereas Ceylon cinnamon only trace amounts thereof [1]. Coumarin (1-benzopyran-2-one) is a compound showing various effects. It is used in the prophylaxis and treatment of lymphedema and chronic venous disease (CVD); it exhibits anti-inflammatory, antithrombotic, sedative and spasmolytic activity $[13,16]$. It has been reported that this compound can inhibit lipid peroxidation, lipoxygenase activity and prevent the chemically generated oxidative stress; also it inhibits the proliferation of many cell lines, e.g., malignant prostate cancer (DU145, LNCaP) and kidney cancer (786-O, A-498) [8, 9]. However for some people with a low cytochrome CYP2A6 activity, it can be hepatotoxic [12]. Laboratory tests on rodents have shown that coumarin could have a genotoxic and carcinogenetic activity; it has caused liver tumours in rats and mice and lung tumours in mice. Yet, such activity was not confirmed on the human organism [4].

The European Food Safety Authority (EFSA) and German Institute for Risk Assessment (BfR) have set a Tolerable Daily Intake (TDI) level of $0.1 \mathrm{mg}$ coumarin per one kg of body weight [17]. Moreover, the European Parliament and Council have set the maximum level of $2 \mathrm{mg} / \mathrm{kg}$ of this compound in food except for cinnamoncontaining, traditional and/or seasonal baked goods with a reference to cinnamon on their labelling, chewing gums $(50 \mathrm{mg} / \mathrm{kg})$, breakfast cereals including muesli $(20 \mathrm{mg} / \mathrm{kg})$, other fine baked goods $(15 \mathrm{mg} / \mathrm{kg})$, alcoholic beverages and special cara- 
mels $(10 \mathrm{mg} / \mathrm{kg})$, and other desserts $(5 \mathrm{mg} / \mathrm{kg})$ [3]. There is no legal regulation regarding the coumarin content in cinnamon [12].

Next to coumarin, cinnamaldehyde is another biologically active compound found in cinnamon; it gives the cinnamon its flavour, aroma and some pro-health properties [5]. It exhibits antifungal, antioxidant, anti-inflammatory, antimicrobial and antipyretic activity [6]. Cinnamaldehyde can inhibit the growth of eggs and adults of human head lice (Pediculus humanus capitis) as well as yeasts and dermatophytes [2]. This substance can be used in the prevention and treatment of diabetes, because it regulates the metabolism of glucose and lipids in the blood and it increases insulin sensitivity [5]. It also inhibits the proliferation of various types of human cancer cells including hepatocellular carcinoma PLC/PRF/5 and HepG2 [11].

The objective of the research study was to evaluate the quality of commercial cinnamon available on the Polish market.

\section{Material and methods}

Commercial samples of cinnamon powder $(n=15)$ and cinnamon sticks $(n=4)$ with the indication of unknown botanical origin were purchased in supermarkets localized in southeast Poland. The samples were delivered by various distributors; only in the case of $37 \%$ of all the samples the country of origin was specified (India, Indonesia and Vietnam). The reference samples consisted of powder $(n=4)$ and sticks $(n=2)$ samples of Ceylon cinnamon from Sri Lanka and Madagascar, and of bark of Chinese cinnamon from China $(n=1)$; they were purchased in a special health food store. The details about the cinnamon samples under analysis are shown in Tab. 1.

Coumarin (> $99 \%$ ), cinnamaldehyde (99\%), methanol, acetonitrile, ethanol (98\%) and orthophosphoric acid were purchased from Sigma-Aldrich (St. Louis, USA). All the solvents used were of a HPLC grade. The ultrapure water was prepared using HLP 5 deionizer (Hydrolab, Poland).

The cinnamon sticks were ground in a laboratory mill (IKA A11, Germany) to produce a fine drug powder. A $2 \mathrm{~g}$ sample of ground cinnamon was extracted for 30 min with a $20 \mathrm{ml}$ of $50 \%(\mathrm{v} / \mathrm{v})$ ethanol solution using an ultrasound-assisted method $(560$ W, 40 kHz; U-504 Ultron, Transfer Multisort Elektronik Sp. z o.o, Łódź, Poland). Then the extracts were centrifuged at $1250 \times \mathrm{g}$ (MPW 315R, Med. Instruments, Warszawa, Poland) for $10 \mathrm{~min}$. Prior to injection, the supernatant was filtered through a nylon filter $(0.20 \mu \mathrm{m})$. Each sample was prepared in duplicate.

The chromatographic separation was carried out using Young Lin YL 9100 HPLC chromatograph with UV-ViS detector YL9120 (YL Instrument Co., Ltd., Korea). There was used a $4.6 \times 250 \mathrm{~mm}, 2.5 \mu \mathrm{m}$ Cosmosil C18 MSII column that was thermostated at $40{ }^{\circ} \mathrm{C}$. The mobile phase consisted of water with orthophosphoric acid $0.01 \%$ $\mathrm{v} / \mathrm{v}$ (phase A), methanol (phase B) and acetonitrile (phase C). A gradient elution at 
a constant flow rate of $0.7 \mathrm{ml} / \mathrm{min}$ was used according to the following program: $80 \%$ A, $5 \% \mathrm{~B}, 15 \% \mathrm{C}(10 \mathrm{~min})$; then it was changed to $65 \% \mathrm{~A}, 20 \% \mathrm{~B}, 15 \%$ (20 min) and for the next $20 \mathrm{~min}$ it returned to the initial conditions. The chromatograms were recorded at $280 \mathrm{~nm}$ and the injection volume was $20 \mu 1$.

Calibration curves were performed by an external standard method using a standard substance at six different concentrations ranging from 0.01 to $10 \mu \mathrm{g} / \mathrm{ml}$. The standards were dissolved in the same solvent, which was used for the extraction of samples $\left(50 \% \mathrm{v} / \mathrm{v}\right.$ ethanol solution). The dilution curves showed good linearity $\left(\mathrm{r}^{2} \geq 0.9997\right)$. The limit of detection (LOD) and the limit of quantification (LOQ) were determined according to a method as described by Solaiman and Al-Zehouri [14]. The calculated LOD and LOQ were, respectively, $0.05 \mu \mathrm{g} / \mathrm{ml}$ and $0.08 \mu \mathrm{g} / \mathrm{ml}$ for coumarin, and $0.02 \mu \mathrm{g} / \mathrm{ml}$ and $0.06 \mu \mathrm{g} / \mathrm{ml}$ for cinnamaldehyde. The analysis repeatability was determined by a triple injection of each cinnamon sample. The relative standard deviations (RSD) were below $1 \%$. The peak area and retention time-based injection repeatability were the measurements by the RSD of three injections of the same standard solutions. The measurements were conducted on the three consecutive days to check an interday variation of precision. The RSD obtained for the peak area stability was less than $0.4 \%$ and $1.2 \%$ in the intraday and interday measurements, respectively. The RSD for the retention time stability was lower than $0.2 \%$ for the two measurements. This meant that the method developed was suitable for the quantification of the substances chosen. The recovery was investigated by spiking the commercial sample of cinnamon (with a known amount of standards) at the three concentration levels (1.5 mg, $3.0 \mathrm{mg}, 6 \mathrm{mg}$ of coumarin, and $6.5 \mathrm{mg}, 13 \mathrm{mg}$ and $26 \mathrm{mg}$ of cinnamaldehyde). The recovery values ranged from 90 to $98 \%$.

The experimental designs and calculations were performed using a StatSoft Statistica 13.0 software (StatSoft, Inc., Tulsa, OK). The results were presented as the mean values with standard deviations (SD). The samples were classified using a Cluster Analysis (CA) and the differences between the groups were calculated by a oneway analysis of variance (ANOVA) followed by a Duncan test $(\mathrm{p}<0.05)$. The correlation between the content of the compounds analysed was determined using a Pearson's correlation test. 


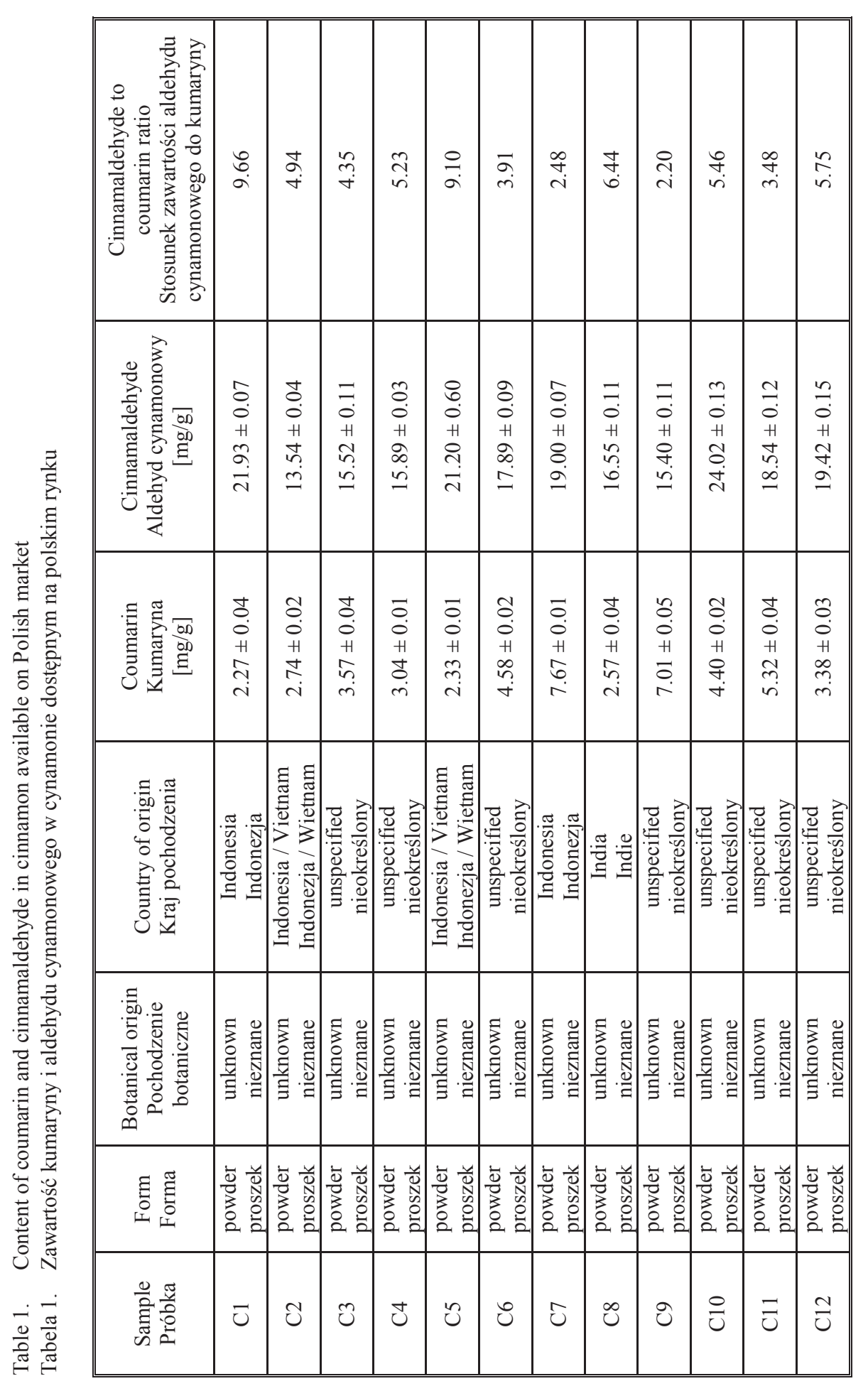




\begin{tabular}{|c|c|c|c|c|c|c|c|c|c|c|c|c|c|}
\hline$\underset{\mathrm{i}}{\tilde{i}}$ & 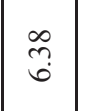 & $\hat{b}$ & $\stackrel{\circ}{\rightarrow}$ & $\begin{array}{l}\tilde{n} \\
\infty \\
\infty\end{array}$ & oे & $\overrightarrow{0}$ & $\begin{array}{l}\infty \\
\stackrel{\infty}{0} \\
\infty \\
\infty\end{array}$ & $\begin{array}{l}\tilde{b} \\
\stackrel{8}{q} \\
\end{array}$ & , & , & 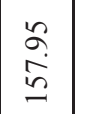 & $\begin{array}{l}\hat{b} \\
\stackrel{0}{0} \\
0\end{array}$ & $\begin{array}{l}\hat{a} \\
\text { Dे } \\
\infty\end{array}$ \\
\hline \begin{tabular}{l}
8 \\
0 \\
+ \\
H \\
\multirow{1}{I}{} \\
$=$
\end{tabular} & $\begin{array}{l}n \\
0 \\
0 \\
+1 \\
+ \\
m \\
\stackrel{2}{2}\end{array}$ & $\begin{array}{l}\grave{\Im} \\
0 \\
+ \\
+ \\
\infty \\
+ \\
\stackrel{0}{2}\end{array}$ & 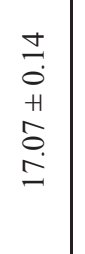 & $\begin{array}{l}\text { I } \\
0 \\
+1 \\
\text { İ } \\
\stackrel{i}{1}\end{array}$ & $\begin{array}{l}8 \\
0 \\
0 \\
H \\
0 \\
0 \\
\infty \\
-\end{array}$ & $\begin{array}{l}\infty \\
0 \\
0 \\
+ \\
\stackrel{+}{0} \\
\stackrel{0}{2} \\
-\end{array}$ & 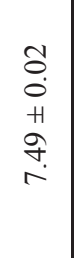 & $\begin{array}{l}\overrightarrow{0} \\
\vdots \\
0 \\
+1 \\
0 \\
0 \\
0 \\
0\end{array}$ & $\begin{array}{l}\overrightarrow{0} \\
\dot{0} \\
+ \\
\ddot{2} \\
\dot{0} \\
i\end{array}$ & 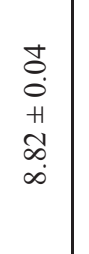 & $\begin{array}{l}8 \\
0 \\
0 \\
+1 \\
= \\
\dot{m}\end{array}$ & $\begin{array}{l}0 \\
0 \\
0 \\
+ \\
\ddot{\alpha} \\
0 \\
0 \\
0\end{array}$ & $\begin{array}{l}\stackrel{a}{\overrightarrow{0}} \\
0 \\
+1 \\
+ \\
\dot{0} \\
\infty\end{array}$ \\
\hline $\begin{array}{l}\overrightarrow{0} \\
0 \\
+ \\
+ \\
n \\
f \\
0\end{array}$ & $\begin{array}{l}\tilde{O} \\
0 \\
+ \\
\ddot{m} \\
\dot{m}\end{array}$ & $\begin{array}{l}0 \\
0 \\
0 \\
+ \\
\dot{0} \\
\stackrel{0}{0} \\
i\end{array}$ & $\begin{array}{l}\tilde{O} \\
\dot{+} \\
+1 \\
\stackrel{0}{0} \\
\infty \\
\infty\end{array}$ & 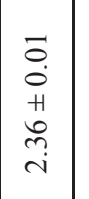 & $\begin{array}{l}\overrightarrow{0} \\
\dot{0} \\
H \\
\hat{0} \\
\dot{0}\end{array}$ & 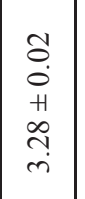 & $\begin{array}{l}8 \\
0 \\
0 \\
H \\
\\
\\
0\end{array}$ & $\begin{array}{l}8 \\
0 \\
0 \\
+1 \\
0 \\
0 \\
0\end{array}$ & $\begin{array}{l}\stackrel{g}{\circ} \\
\stackrel{]}{v}\end{array}$ & $\underset{\mathrm{V}}{\stackrel{\mathrm{g}}{\mathrm{G}}}$ & 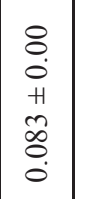 & $\begin{array}{l}8 \\
0 \\
0 \\
+1 \\
0 \\
0 \\
0 \\
0\end{array}$ & $\begin{array}{l}0 \\
0 \\
0 \\
+ \\
0 \\
0 \\
0 \\
0\end{array}$ \\
\hline 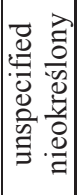 & 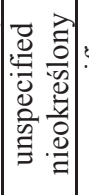 & 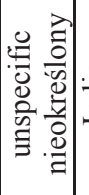 & : & 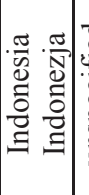 & 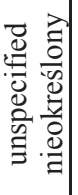 & 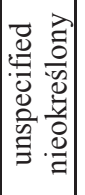 & 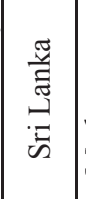 & 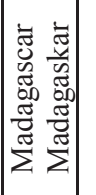 & 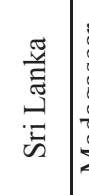 & 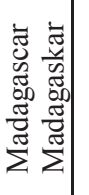 & 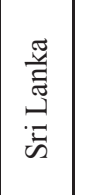 & 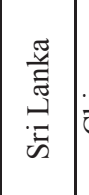 & 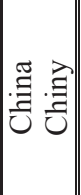 \\
\hline 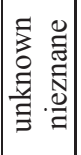 & 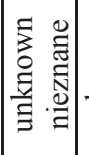 & 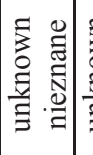 & 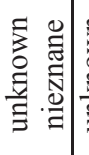 & 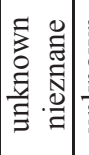 & 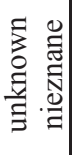 & 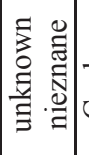 & 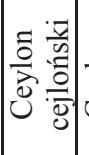 & 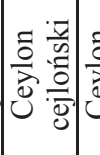 & 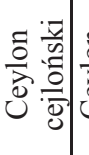 & 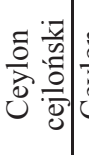 & 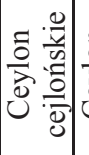 & 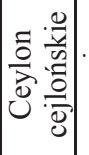 & 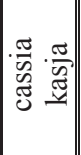 \\
\hline 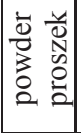 & 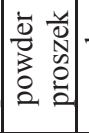 & 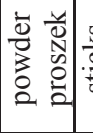 & 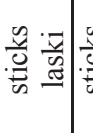 & 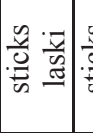 & 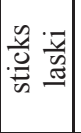 & 证 & 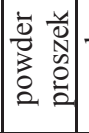 & 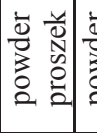 & 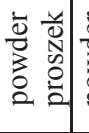 & 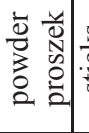 & 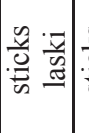 & 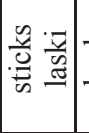 & 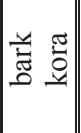 \\
\hline$\stackrel{m}{U}$ & $\stackrel{\nabla}{U}$ & $\frac{n}{u}$ & 己 & $\bar{u}$ & $\stackrel{\infty}{\circlearrowright}$ & $\overrightarrow{\vec{U}}$ & ત્రి & $\overrightarrow{\widetilde{U}}$ & తี & 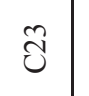 & $\stackrel{\mathbb{U}}{J}$ & $\tilde{\mho}$ & ర్ \\
\hline
\end{tabular}




\section{Results and discussion}

The contents of coumarin and cinnamaldehyde were determined by the HPLC method. The chromatograms were generated and the peaks of coumarin and cinnamaldehyde were identified based on the corresponding retention time at 20.3 and $39.4 \mathrm{~min}$, respectively (Fig. 1). The coumarin content obtained for each group was presented in Tab. 1. Coumarin was detected in all of the commercial samples excluding two samples of Ceylon cinnamon. The amount of this compound in cinnamon with the unknown botanical origin ranged from 2.27 to $7.67 \mathrm{mg} / \mathrm{g}$ in the powder samples and from 2.36 to $8.7 \mathrm{mg} / \mathrm{g}$ in the stick samples. Important was that the three samples of the commercial cinnamon sticks with the unknown botanical origin exhibited a very similar value and only in one sample the content of this compound was three times the above indicated amount.

A)

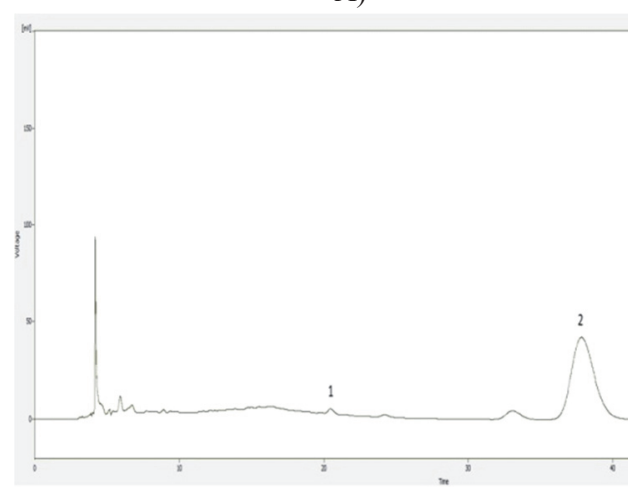

B)

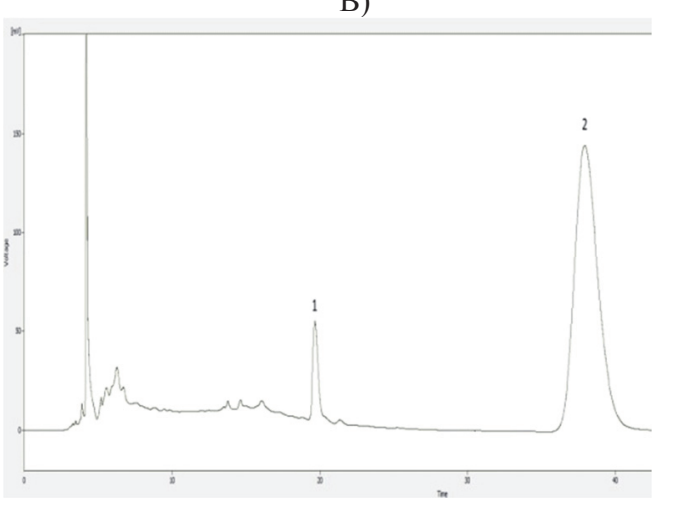

Fig. 1. Chromatograms of Ceylon cinnamon (A) and of cinnamon with unspecified botanical origin (B)

Rys. 1. Chromatogramy cynamonu cejlońskiego (A) i cynamon bez określonego pochodzenia botanicznego (B)

The findings of other scientists confirm that the commercial cinnamon highly varies in terms of the coumarin content. Blavova and Svobodova [2] found coumarin in the commercial cinnamon available on Czech market to be on a comparable level that ranged from 2.65 to $7.02 \mathrm{mg} / \mathrm{g}$. Similarly Lungarini et al. [12], who focused on the Italian market, found highly differentiated concentrations of this compound - from 3 to $4.44 \mathrm{mg} / \mathrm{g}$. In the ground cinnamon samples available on the USA market the coumarin content ranged between 2.00 and $6.19 \mathrm{mg} / \mathrm{g}$ [17]. In turn, in the samples purchased from retail shops in South India the content of this substance was between 0.82 and $3.46 \mathrm{mg} / \mathrm{kg}$ [1]. Sproll et al. [15] and Woehrlin et. al [18] also reported a large diversity 
in the content of coumarin in cinnamon available on the German market - from below the detection limit to even $8.79 \mathrm{mg} / \mathrm{g}$ and $9.90 \mathrm{mg} / \mathrm{g}$ of coumarin, respectively.

In the authors' own study the powdered and stick samples of Ceylon cinnamon (Cinnamomum verum) contained on average 0.05 and $0.014 \mathrm{mg} / \mathrm{g}$ of coumarin, respectively. This is consistent with the findings of Ananthakrishnan et al. [1], who determined a much lower amount of coumarin in C. verum - from below the detection limit to $0.14 \mathrm{mg} / \mathrm{g}$ [1]. A small amount $(0.066 \mathrm{mg} / \mathrm{g})$ of coumarin was also detected in the bark of Chinese Cassia cinnamon (C. aromaticum). This product could be undesirable for customers owing to its bark form, however after grinding it tastes and smells like the commercial cinnamon available on the retail market. In the samples of original $C$. cassia barks $\mathrm{He}$ et al. [6] found a coumarin level that ranged between 0.04 and $0.85 \mathrm{mg} / \mathrm{g}$, whereas Wang et. al [17] determined the level of this compound to be $0.31 \mathrm{mg} / \mathrm{g}$ in a true sample and $0.17 \mathrm{mg} / \mathrm{g}$, on average, in the commercial cinnamon barks.

Similarly to the content of coumarin, the content of cinnamaldehyde also varied depending on the botanical and geographical origin of the cinnamon samples (Tab. 1). However, the content of this substance was not correlated with the coumarin level (Pearson's coefficient value 0.233). In the commercial cinnamon powder of the unknown cinnamon species its level ranged between 13.48 and $24.02 \mathrm{mg} / \mathrm{g}$, whereas in the sticks it ranged between 17.07 and $20.22 \mathrm{mg} / \mathrm{g}$ (Fig. 1). As regards Ceylon cinnamon, that compound was identified at a lower level, i.e. it ranged from 5.89 to $8.82 \mathrm{mg} / \mathrm{g}$ in the powdered cinnamon and it was ca. $12 \mathrm{mg} / \mathrm{g}$ in the sticks, respectively. A much higher amount of that compound was reported in the bark of Chinese Cassia cinnamon $-38.74 \mathrm{mg} / \mathrm{g}$. The authors' own results were similar to the findings of other researchers. He et al. [6] suggested that the content of cinnamaldehyde could be applied to differentiate $C$. cassia from other species. In their study, the true $C$. cassia contained from 13.05 to $48.29 \mathrm{mg} / \mathrm{g}$ of cinnamaldehyde. If compared with other species (C. wilsonii, C. japonicum, C. burmannii and C. mairei), the level of this particular compound was below $10 \mathrm{mg} / \mathrm{g}$. According to the information available in the Chinese pharmacopoeia, a quality cortex cinnamon should not contain less than $10 \mathrm{mg} / \mathrm{g}$ [6]. Quite different results were obtained by Wang et al. [17]; they determined the highest content of cinnamaldehyde in C. burmannii $(12.4 \div 63.8 \mathrm{mg} / \mathrm{g})$ and C. loureiroi $(55.8 \div$ $76.1 \mathrm{mg} / \mathrm{g}$ ). Wang et al. found a relatively lower amount thereof; its average content value was $11.24 \mathrm{mg} / \mathrm{g}$ in C. verum and $18.45 \mathrm{mg} / \mathrm{g}$ in the C. cassia barks. As regards the cinnamon available on the Italian market, high variations were reported in the contents of cinnamaldehyde [12]. Additionally, compared to the commercial samples, a lower amount of cinnamaldehyde in the true $C$. verum was found by Ananthakrishnan et al. [1]. Average content values of coumarin and cinnamaldehyde for each group of the product analysed are shown in Fig. 2. 


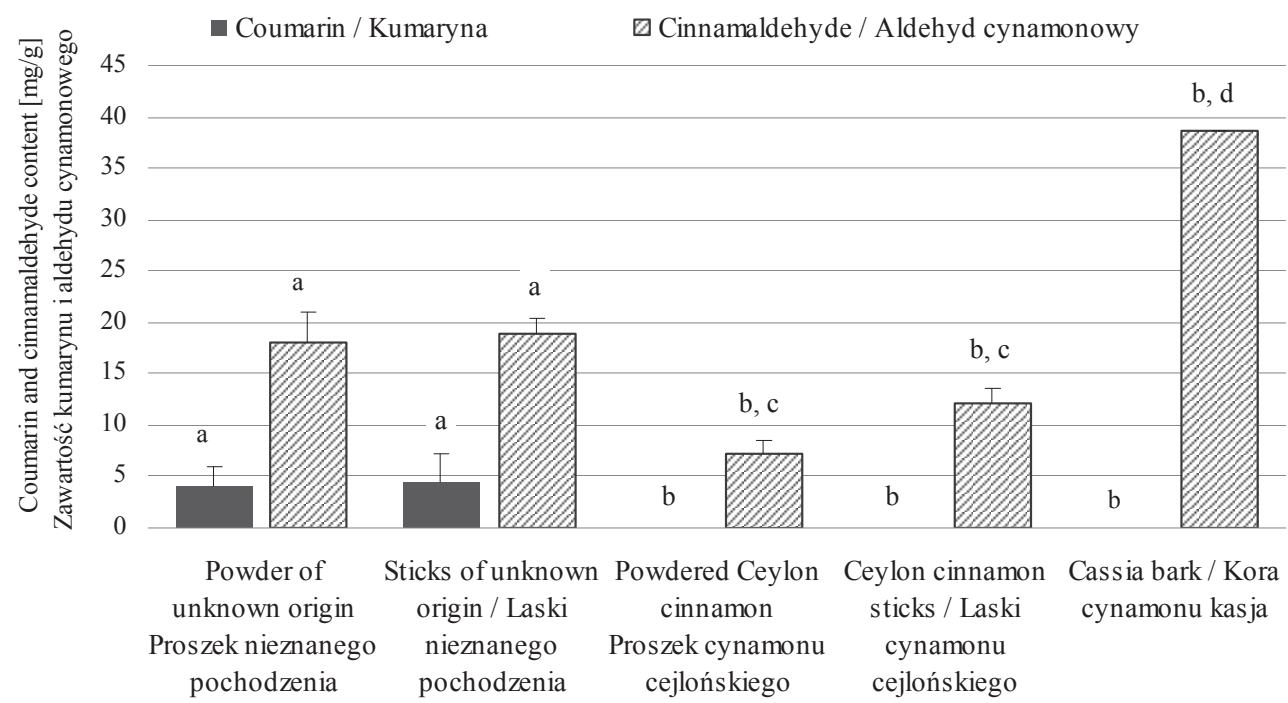

Explanatory notes / Objaśnienia:

Figure shows mean values (bars) and standard deviations (line segments) / Na rysunku przedstawiono wartości średnie (w postaci słupków) i odchylenia standardowe (w postaci odcinków); a - d - mean values denoted by different letters differ statistically significantly between groups of tested products tested $(\mathrm{p}<0.05)$ / wartości średnie oznaczone różnymi literami różną się statystycznie istotnie pomiędzy grupami badanych produktów $(\mathrm{p}<0,05)$.

Fig. 2. Content of coumarin and cinnamaldehyde in cinnamon available on Polish market

Rys. 2. Zawartość kumaryny i aldehydu cynamonowego w cynamonie dostępnym na polskim rynku

In order to find similarities among the samples analysed and to classify them, a Cluster Analysis (CA) was carried out. In the cluster scheme the samples were divided into three different groups (Fig. 3). The longest linkage distance was reported in the case of Cassia cinnamon bark (C26 sample, the bond distance to other groups was 2.7). The linkage distance among the cinnamon samples with the unspecified botanical origin and the Ceylon cinnamon samples was 1.03 . Within the group studied, it was 0.7 as for the samples with the unspecified origin of cinnamon (C1 - C10 samples) and 0.3 as for the Ceylon cinnamon samples (C20 - C24 samples). Also, it was shown that the cinnamon with the unspecified botanical origin varied as regards the parameters tested.

Following the idea of Wang et al. [17] of using cinnamaldehyde-to-coumarin content ratio to differentiate the Cinnamomum species, the values were determined of this indicator for the groups classified by CA method (Tab. 2). A remarkable difference was reported between the ratios of cinnamaldehyde-to-coumarin content: below 10 as for the unknown samples, between 157 and 680 as for C. verum and 569 as for C. cassia. 


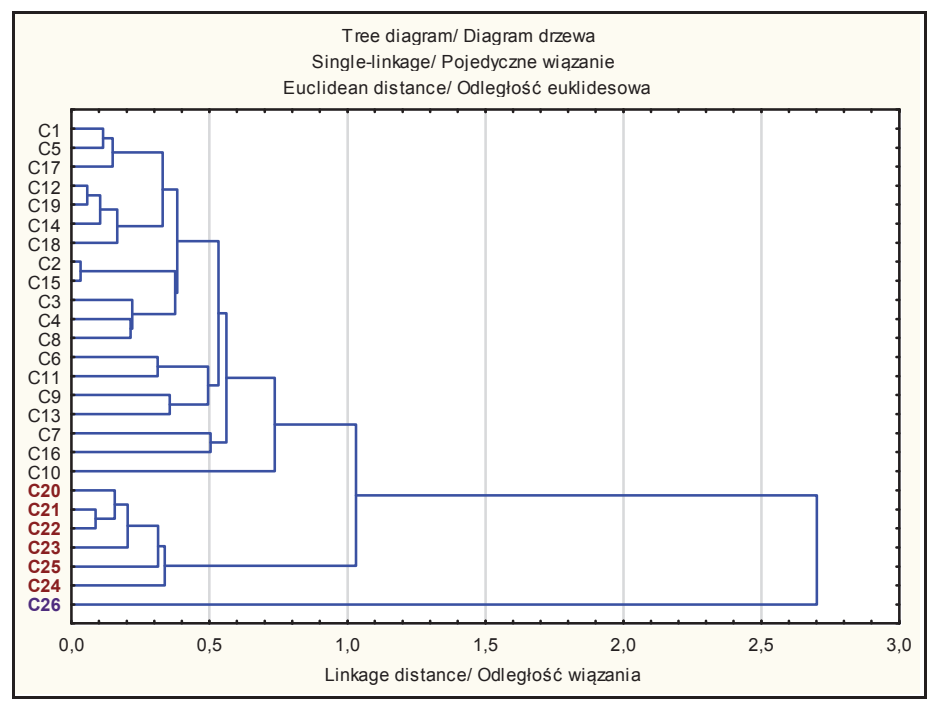

Fig. 3. Classification of cinnamon samples available on Polish market on the basis of Cluster Analysis that covers content of coumarin and of cinnamaldehyde

Rys. 3. Klasyfikacja próbek cynamonu dostępnego na polskim rynku na podstawie analizy skupień obejmującej zawartość kumaryny i aldehydu cynamonowego

Table 2. Separated groups of cinnamon available on Polish market on the basis of results of Cluster Analysis including computed cinnamaldehyde-to-coumarin content ratio

Tabela 2. Wyodrębnione grupy cynamonu dostępnego na polskim rynku na podstawie wyników analizy skupień wraz z obliczonym stosunkiem zawartości aldehydu cynamonowego do kumaryny

\begin{tabular}{|c|c|c|c|c|c||}
\hline $\begin{array}{c}\text { Group } \\
\text { Grupa }\end{array}$ & $\begin{array}{c}\text { Sample } \\
\text { Próbka }\end{array}$ & $\begin{array}{c}\text { Statistical } \\
\text { measure } \\
\text { Miara } \\
\text { statystyczna }\end{array}$ & $\begin{array}{c}\text { Coumarin } \\
\text { Kumaryna } \\
{[\mathrm{mg} / \mathrm{g}]}\end{array}$ & $\begin{array}{c}\text { Cinnamaldehyde } \\
\text { Aldehyd cynamonowy } \\
{[\mathrm{mg} / \mathrm{g}]}\end{array}$ & $\begin{array}{c}\text { Cinnamaldehyde } \\
\text { vs. coumarin } \\
\text { Aldehyd cynamonowy } \\
\text { vs. kumaryna }\end{array}$ \\
\hline G1 & $\mathrm{C} 26$ & $\overline{\mathrm{X}} \pm \mathrm{SD}$ & $0.07^{\mathrm{a}} \pm 0.01$ & $38.74^{\mathrm{a}} \pm 0.19$ & $568.97^{\mathrm{a}} \pm 0.00$ \\
\hline G2 & $\mathrm{C} 20-\mathrm{C} 25$ & $\begin{array}{c}\mathrm{x}_{\min }-\mathrm{X}_{\max } \\
\overline{\mathrm{X}} \pm \mathrm{SD}\end{array}$ & $\begin{array}{c}<\mathrm{LOQ}-0.08 \\
0.03^{\mathrm{a}} \pm 0.03\end{array}$ & $\begin{array}{c}5.89-13.11 \\
8.78^{\mathrm{b}} \pm 2.78\end{array}$ & $\begin{array}{c}157-680 \\
362.98^{\mathrm{b}} \pm 244.97\end{array}$ \\
\hline G3 & $\mathrm{C} 1-\mathrm{C} 19$ & $\begin{array}{c}\mathrm{x}_{\min }-\mathrm{x}_{\max } \\
\overline{\mathrm{X}} \pm \mathrm{SD}\end{array}$ & $\begin{array}{c}2.27-8.70 \\
4.41^{\mathrm{b}} \pm 1.97\end{array}$ & $13.48-24.02$ & $1.96-9.66$ \\
$18.19^{\mathrm{c}} \pm 2.78$ & $5.25^{\mathrm{c}} \pm 2.23$ \\
\hline
\end{tabular}

Explanatory notes / Objaśnienia:

$\overline{\mathrm{X}}$ - mean value / wartość średnia; SD - standard deviation / odchylenie standardowe; a, b, c - mean values denoted by different letters differ statistically significantly among groups $(p<0.05) /$ wartości średnie oznaczone różnymi literami różną się statystycznie istotnie pomiędzy grupami $(\mathrm{p}<0,05)$.

In most cases in Poland the type and origin of cinnamon are not labelled on the spice package. It is supposed that the commercial cinnamon samples studied are probably $C$. burmannii and $C$. loureiroi; this statement is based on the analysis of the data 
received, the comparison of those data with the data reported in other studies, and also on the information of the country of origin (mainly from Indonesia and Vietnam). Considering that the commercial samples contain a significant amount of coumarin, its high consumption could be harmful for the human organism since it exceeds the TDI level. However Iwata et al. [7] studied the correlation between hepatotoxicity and the coumarin intake from Kampo medicines (traditional Japanese medicine containing a cinnamon bark) and they concluded that coumarin contained in those medicines, even if it exceeded the TDI value, was not correlated with hepatotoxicity.

\section{Conclusions}

1. The results obtained proved a high variation in coumarin and cinnamaldehyde contents in the cinnamon available on the Polish market.

2. The highest content of coumarin was reported in the samples without the specified botanical origin of the spice tested; it was much higher than that as reported in the Ceylon cinnamon used as reference. Simultaneously, the samples studied were richer in cinnamaldehyde.

3. Based on the cinnamaldehyde-to-coumarin content ratio it was found that on the Polish market mainly the low-cost cassia cinnamon is available and its botanical and geographical origin is unspecified.

\section{Acknowledgements}

The research was funded from project under the Minister of Science and Higher Education programme "Regionalna Inicjatywa Doskonałości" for the years 2019 2022, project no. 026/RID/2018/19, funding amount PLN 9542500.00.

\section{References}

[1] Ananthakrishnan R., Chandra P., Kumar B., Rameshkumar K.B.: Quantification of coumarin and related phenolics in cinnamon samples from south India using UHPLC-ESI-QqQLIT-MS/MS method. Int. J. Food Prop., 2018, 21 (1), 50-57.

[2] Blahova J., Svobodova Z.: Assesment of coumarin levels in ground cinnamon available in the Czech retail market. Sci. World J., 2012, \#263851. DOI: 10.1100/2012/263851.

[3] Regulation (EC) No 1334/2008 of the European Parliament and of the Council of 16 December 2008 on flavourings and certain food ingredients with flavouring properties for use in and on foods and amending Council Regulation (EEC) No 1601/91, Regulations (EC) No 2232/96 and (EC) No 110/2008 and Directive 2000/13/EC. O. J. L 354, pp. 34-50, of 31.12.2008.

[4] Felter S.P., Vassallo J.D., Carlton B.D., Daston G.P.: A safety assessment of coumarin into account species-specificity of toxicokinetics. Food Chem. Toxicol., 2006, 44, 462-475.

[5] Hamidpour R., Hamidpour M., Hamidpour S., Shahlari M.: Cinnamon from the selection of traditional applications to its novel effects on the inhibition of angiogenesis in cancer cells and prevention of Alzheimer's disease, and a series of functions such as antioxidant, anticholesterol, antidiabe- 
tes, antibacterial, antifungal, nematicidal, acaracidal, and repellent activities. J. Tradit. Complement. Med., 2015, 5(2), 66-70.

[6] He Z.D., Qiao C.F., Han Q.B., Chieng C.L., Xu H.X., Jiang R.W., But P.H., Shaw P.C.: Authentication and quantitative analysis on the chemical profile of cassia bark (cortex cinnamomi) by highpressure liquid chromatography. J. Agric. Food Chem., 2005, 53(7), 2424-2428.

[7] Iwata N., Kainuma M., Kobayashi D., Kubota T., Sugawara N., Uchida A., Ozono S., Yamamuro Y., Furusyo N., Ueda K., Tahara E., Schimazoe T.: The relation between hepatotoxicity and the total coumarin intake from traditional Japanese medicines containing cinnamon bark. Front. Pharmacol., 2016. DOI: 10.3389/fphar.2016.00174.

[8] Khan N., Sharma S., Sultana S.: Amelioration of ferric nitrilotriacetate (Fe-NTA) induced renal oxidative stress and tumor promotion response by coumarin (1,2-benzopyrone) in Wistar rats. Cancer Lett., 2004, 210 (1),17-26.

[9] Kubrak K., Podgórski R., Stompor M.: Natural and synthetic coumarins and their pharmacological activity. Eur. J. Clin. Exp. Med., 2017, 15 (2), 169-175.

[10] Li R., Wang Y., Jiang Z., Jiang S.: Chemical composition of the essential oils of Cinnamomum loureirii Nees. from China obtained by hydrodistillation and microwave-assisted hydrodistillation. J. Essent. Oil Res., 2010, 22, 129-131.

[11] Lin L.T., Wu S.J., Lin C.C.: The anticancer properties and apoptosis-inducing mechanisms of cinnamaldehyde and the herbal prescription Huáng Lián Jiě Dú Tang in human hepatoma cells. J. Tradit. Complement. Med., 2013, 3(4), 227-233.

[12] Lungarini S., Aureli F., Coni E.: Coumarin and cinnamaldehyde in cinnamon marketed in Italy: A natural chemical hazard? Food Addit. Contam. Part A, 2008, 25 (11), 1297-1305.

[13] Perrin M., Ramelet A.A.: Pharmacological treatment of primary chronic venous disease: Rationale, results and unanswered questions. Eur. J. Vasc. Endovasc. Surg., 2011, 41 (1), 117-125.

[14] Solaiman R., Al-Zehouri J.: Determination of coumarin in methanol extract of cinnamon (Cinnamomum cassia Blume) using reversed-phase high liquid chromatography. J. Pharmacogn. Phytochem., 2017, 6(4), 726-729.

[15] Sproll C., Winfried R., Andlauer C., Godelmann R., Lachenmeier D.W.: HPLC analysis and safety assessment of coumarin in foods. Food Chem., 2008, 109, 462-469.

[16] Venugopala K.N., Rashmi V., Odhav B.: Review on natural coumarin lead compounds for their pharmacological activity. Biomed Res. Int., 2013, \#963248. DOI: 10.1155/2013/963248.

[17] Wang Y.H., Avula B., Nanayakkara N.P., Zhao J., Khan I.A.: Cassia cinnamon as a source of coumarin in cinnamon-flavored food and food supplements in the United States. J. Agric. Food Chem., 2013, 61(18), 4470-4476.

[18] Woehrlin F., Fry H., Abraham K., Preiss-Weigert A.: Quantification of flavouring constituents in cinnamon: High variation of coumarin in cassia bark from the German retail market and in authentic samples from Indonesia. J. Agric. Food Chem., 2010, 58, 10568-10575.

[19] Zhu R., Liu H., Liu C., Wang L., Ma R., Chen B., Li L., Niu J., Fu M., Zhang D., Gao S.:. Cinnamaldehyde in diabetes: A review of pharmacology pharmacokinetics and safety. Pharmacol. Res., 2017, 122, 78-89. 


\title{
OCENA JAKOŚCI CYNAMONU DOSTĘPNEGO NA POLSKIM RYNKU NA PODSTAWIE OKREŚLENIA STOSUNKU ZAWARTOŚCI ALDEHYDU CYNAMONOWEGO I KUMARYNY
}

\author{
Streszczenie
}

Na europejskim rynku dostępne są głównie dwie odmiany cynamonu - cynamon cejloński i kasja. Cynamon kasja różni się od cynamonu cejlońskiego pod względem smaku, zapachu, postaci, a przede wszystkim zawartości kumaryny. Kasja zawiera nawet do 10,6 \% tego związku, podczas gdy cynamon cejloński jedynie śladowe jego ilości.

Celem pracy była ocena jakości cynamonu dostępnego na polskim rynku przy użyciu metody HPLC. Dwadzieścia sześć próbek komercyjnego cynamonu w postaci proszku $(\mathrm{n}=19)$, lasek $(\mathrm{n}=6)$ i kory $(\mathrm{n}=1)$ analizowano pod względem zawartości kumaryny i aldehydu cynamonowego. Spośród analizowanych próbek cynamonu $73 \%$ nie zawierało na etykiecie informacji dotyczącej pochodzenia botanicznego (określone jako „nieznane”). Próbki oznaczone na etykiecie jako Cinnamomum verum $(\mathrm{n}=6)$ oraz Cinnamomum cassia $(\mathrm{n}=1)$ użyto jako próbek odniesienia. Największą zawartością kumaryny $(2,3 \div$ $7,7 \mathrm{mg} / \mathrm{g}$ ) cechowały się próbki o nieznanym pochodzeniu, najmniejszą zaś próbki C. verum oraz C. cassia (do $0,08 \mathrm{mg} / \mathrm{g}$ ). Zawartość aldehydu cynamonowego wyniosła 38,7 mg/g - C cassia, $19 \mathrm{mg} / \mathrm{g}$ - ,nieznane" i $9 \mathrm{mg} / \mathrm{g}-$ C. verum. Stosunek zawartości aldehydu cynamonowego do zawartości kumaryny był bardzo zróżnicowany. W przypadku próbek o niezidentyfikowanym pochodzeniu wyniósł on poniżej 10, natomiast próbki odniesienia charakteryzowały się stosunkiem $157 \div 680$. Wykazano, że na polskim rynku w większości sprzedawany jest cynamon kasja - jako tania przyprawa bez deklaracji producenta o pochodzeniu botanicznym.

Słowa kluczowe: cynamon, kumaryna, aldehyd cynamonowy, analiza HPLC, weryfikacja pochodzenia 